\title{
PULMONARY HEART DISEASE ACUTE AND CHRONIC
}

\author{
September 10, 1947, morning. Joint Meeting with Section of Diseases of the Chest
}

\section{By J. McMichael, London}

Heart failure from primary disorder of the lungs may be classified as follows.

Acute. Pulmonary embolism.

Subacute. Miliary carcinoma.

Chronic. (1) Primary pulmonary hypertension.

(2) Secondary to lung disease.

Emphysema (Bronchitis, Bronchiectasis, Cystic disease).

Pneumoconiosis (Silicosis, Anthraco-silicosis).

Pulmonary fibrosis (Fibroid tuberculosis, Scleroderma).

(3) Kyphoscoliosis.

Acute pulmonary embolism. Recognized by circulatory collapse, raised venous pressure, electrocardiographic and other signs of right heart strain.

Chronic cor pulmonale. Commonest cause is emphysema. Capacity of lung vessels in health is approximately $800 \mathrm{ml}$. and this volume is mainly in the capillaries. Obliteration of half the vascular bed in the lungs by ligation of left pulmonary artery produces no rise of pulmonary artery pressure. Best measurement of anatomical lung damage is percentage of residual air in total lung volume. Normal average 28 , range $16-40$ per cent; anything over 60 denotes severe emphysema. Optical records of systolic right ventricular pressure also measure pulmonary artery systolic pressure. Normal range 18-30 mm. Hg. In emphysema without heart failure this pressure is often raised, but there is no correlation between residual air percentage and degree of pulmonary hypertension. It is therefore unlikely that anatomical damage to lungs is itself directly responsible for pulmonary hypertension.

In heart failure from emphysema cardiac output is normal or above normal except when blood pressure falls terminally.

High output failure. This group includes (1) subjects with circulatory shunts which are parasitic on normal circulation (arteriovenous aneurysms,
Paget's disease of bone), (2) conditions demanding an excessively rapid circulation due to deficiency of available oxygen (anæmia, cor pulmonale), (3) beri-beri. The rapid circulation is achieved by a rise in venous pressure, even though œdema also appears.

Clinical Features. General dusky cyanosis, warm hands, and good peripheral pulse. (Contrast cold blue hands and ears of low output failure resulting from hypertension, valvular and ischæmic heart disease.) Often an exacerbation of chronic bronchitis; in absence of this, orthopnœa strikingly absent. Auricular fibrillation unusual. Terminally pulmonary œdema often present. Radiologically enlargement of pulmonary artery. Electrocardiographic signs of right heart stress.

Treatment. Oxygen tent and penicillin aerosol inhalation. Venesection lowers cardiac output. Digoxin usually does the same, and both procedures may be harmful.

Some clinical varieties. (1) Acute circulatory collapse from valvular pneumothorax or large bulla, due to loss of negative intrathoracic pressure and defective filling of the heart with resulting fall in output. (2) Miliary carcinomatosis. Oxygen saturation of arterial blood falls, cardiac output rises, often with rise in venous pressure. (3) Primary pulmonary hypertension occurs with no disease in lungs other than increased vascular resistance. (4) Scleroderma may be associated with fibroid changes in the lungs and right heart strain. (5) Kyphoscoliosis. Cor pulmonale a well recognized terminal event in such patients.

Lung vessels are sensitive to falling oxygen tension which causes vaso-constriction of pulmonary arterioles (Cournand, Von Euler and Liljestrand). Defective ventilation causes closure of the pulmonary circulation in atelectatic and pneumonic lobes. This reaction may also produce pulmonary hypertension in emphysematous, fibrotic, and miliary carcinomatous lungs. 


\section{la Pression Ventriculaire Droite Moyenne (P.V.D.M.) Dans Certaines} AfFections Broncho-PUlmonaIRES Chroniques

\section{Par J. Lenègre et P. Maurice, Paris}

. L'hypertension dans la circulation artérielle * pulme aire est considérée depuis longtemps comme un des principaux facteurs qui expliquent l'évolution possible de certaines affections broncho-pulmonaires chroniques vers l'insuffisance ventriculaire droite. Mais cette conception, quoique basée sur des arguments cliniques, radiologiques, électriques et anatomiques, é-tait seulement jusque dans ces dernières années une hypothèse plausible, puisque les médecins étaient incapables de mesurer chez l'homme la pression dans la petite circulation.

Depuis six ou sept ans, des recherches poursuivies aux Etats-Unis, en France et en Angleterre, ont permis de mesurer chez l'homme la pression qui règne dans les cavités droites du cœur et même dans l'artère pulmonaire.

En 1941, Richards et al, de New-York, les premiers à notre connaissance, puis en 1944, McMichael et Scharpey-Schafer, de Londres, font connaitre les chiffres de la pression auriculaire droite chez l'homme normal et en état d'insuffisance cardiaque. En décembre 1943, Lauson, Bloomfield, Breed, et Cournand rapportent quelques chiffres de pression ventriculaire droite (systolique, diastolique et différentielle) à l'état normal et chez les cardiaques. En Mai 1944, Lenegre et Maurice exposent leurs premiers résultats de la mesure de la P.V.D.M. chez 51 sujets dotés d'un coeur normal ou atteints de cardiopathies diverses. Depuis, ces recherches se sont multipliées aux Etats-Unis (Bing, Vandam, et Gray, Jr.), au Mexique, au Danemark (Tybjaerg, Hansen, et Warburg), en Suède.

Il est donc inopportun de reprendre en détail la technique actuellement bien connue de la cathétérisation du coeur droit : une sonde stérilisée est introduite aseptiquement par une veine du pli du coude (de préférence la basilique) jusque dans l'oreillette droite ou le ventricule droit. Personnellement nous utilisons une sonde uretérale $n^{\circ} 13$, longue de 120 centimètres, que nous faisons pénétrer dans la veine par dénudation sanglante ou grâce à un trocart dont le calibre intérieur est de $2,4 \mathrm{~mm}$. Faute d'un matériel plus précis, nous mesurons avec un manomètre anéroïde (Claude) la pression moyenne qui régne dans les cavités droites, notamment dans le ventricule droit. La technique est à la fois sûre et simple. Si elle connait quelques échecs, dûs souvent à des spasmes veineux, elle est inoffensive. Elle n'est suivie d'aucun incident, sauf parfois d'une induration un peu douloureuse et très passagère de la veine ponctionnée.
Nos premières recherches nous ont conduits à considérer que la P.V.D.M. varie suivant les sujets à l'état normal entre 10 et $20 \mathrm{~cm}$. d'eau, soit 7.5 à $15 \mathrm{~mm}$. de mercure. Le chiffre moyen est de 15.5 cm. d'eau, soit $12 \mathrm{~mm}$. de mercure.

Le but de cette communication est d'exposer les chiffres de P.V.D.M. recueillis par 42 explorations chez 41 sujets atteints: $1^{\circ}-d^{\prime}$ 'une affection bronchopulmonaire chronique avec ou sans catarrhe bronchique: asthme (8 cas), emphysème (13 cas), silicose ou asbestose (13 cas), tuberculose fibreuse ( 1 cas), dyspnée de cause inconnue ( 1 cas); $2^{\circ}-$ d'une cyphoscoliose accentuée avec gibbosité ( 4 cas); $3^{\circ}$-d'une thrombose primitive des deux artères pulmonaires (1 cas). Chez ces 41 malades, l'insuffisance cardiaque, et notamment une insuffisance ventriculaire droite typique (coeur pulmonaire chronique), était présente 10 fois.

Nous avons divisé ces 41 sujets en 2 groupes suivant que leur affection était bien ou mal tolérée. Nous avons admis que les signes suivants étaient les indices d'une mauvaise tolérance : $1^{\circ}$-dyspnée accentuée au repos ou au moindre effort, limitant plus ou moins l'activité sociale; $2^{\circ}$-cyanose; $3^{\circ}$ bruit de galop droit, gros coeur, gros foie, oedèmes des membres inférieurs. Nos résultats sont consignés dans les deux tableaux suivants.
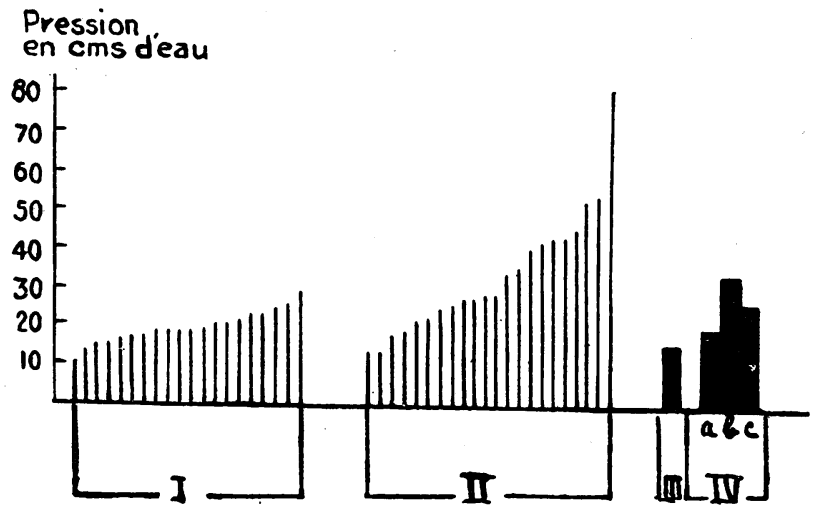

Pression ventriculaire droite moyenne (P.V.D.M.) chez 41 sujets atteints d'une affection broncho-pulmonaire chronique avec ou sans catarrhe bronchique (asthme, emphysème, silicose, sclérose tuberculeuse), ou d'une cyphoscoliose accentuée ou d'une insuffisance ventriculaire droite.

I-Affection broncho-pulmonaire bien tolérée (20 cas). II-Affection broncho-pulmonaire mal tolérée (22 mesures chez 21 malades). III-P.V.D.M. chez le sujet normal $(15 \mathrm{~cm}$. d'eau). IV-P,V.D.M. dans les affections broncho-pulmonaires chroniques: a) bien tolérées: $18.7 \mathrm{~cm}$. d'eau: b) mal tolérées: 33 cm. d'eau: c) moyenne générale: $26 \cdot 2 \mathrm{~cm}$. d'eau. 
Il ressort les faits suivants :

(1)-Dans 20 cas d'affection broncho-pulmonaire chronique (ou autre) bien tolérée, la P.V.D.M. est:

-14 fois mormale $(10$ à $10 \mathrm{~cm}$. d'eau, soit 7.5 à $15 \mathrm{~mm}$. de mercure).

-3 fois à peine supérieure à la normale (21 à $22 \mathrm{~cm}$. d'eau, soit $16 \mathrm{~mm}$. de mercure).

-3 fois modérément augmentée $(24$ à $28 \mathrm{~cm}$. d'eau, soit 18 à $21 \mathrm{~mm}$. de mercure).

Le chiffre moyen, calculé sur ces 20 cas, est de $18.7 \mathrm{~cm}$. d'eau (14 mm. de mercure), e'est-à-dire voisin de la normale.

(2)-Sur les 22 mesures effectuées chez 21 sujets atteints d'une affection broncho-pulmonaire chronique (ou autre) mal tolérée, la P.V.D.M. est:

-4 fois normale $(13$ à $18 \mathrm{~cm}$. d'eau, soit 10 à $15 \mathrm{~mm}$. de mercure).

-2 fois à peine supérieure à la normale (21 à $22 \mathrm{~cm}$. d'eau, soit $16 \mathrm{~mm}$. de mercure).

-16 fois franchement ou considérablement augmentée $(25$ à $80 \mathrm{~cm}$. d'eau, soit 19 à $60 \mathrm{~mm}$. de mercure).

Le chiffre moyen calculé sur les 22 mesures est de $33 \mathrm{~cm}$. d'eau ( $25 \mathrm{~mm}$. de mercure), soit plus du double du chiffre normal.

(3)-La moyenne générale des chiffres de P.V.D.M., calculée d'après nos 42 explorations chez 41 sujets atteints d'affections broncho-pulmonaires chroniques diverses, bien ou mal tolérées, s'établit à $26 \cdot 2 \mathrm{~cm}$. d'eau $(20 \mathrm{~mm}$. de mercure). Elle est donc franchement élevée.

La confrontation des chiffres de la P.V.D.M. avec les signes cliniques, radiologiques ou électriques, montre que, dans l'ensemble, plus la maladie broncho-pulmonaire est sévère et plus l'hypertension ventriculaire droite est élevée. Le fait est particulièrement évident dans les cas d'insuffisance ventriculaire droite avérée, qui correspondent comme on peut le voir sur le deuxième tableau, aux chiffres les plus forts, à savoir, $35,40,41,42,44,52,53$ et $80 \mathrm{~cm}$. d'eau, soit 26 à $60 \mathrm{~mm}$. de mercure.

Dans 6 cas cependant ou la maladie bronchopulmonaire chronique peut passer pour bien tolérée, la P.V.D.M. est déjà élevéè $(21$ à $28 \mathrm{~cm}$. d'eau, soit 16 à $21 \mathrm{~mm}$. de mercure). Cette hypertension dans la circulation artérielle pulmonaire représente fort probablement un indice défavorable. L'avenir montrera si l'évolution s'est faite plus rapidement chez ces malades vers l'insuffisance ventriculaire droite.

Inversement, dans 4 cas où l'affection bronchopulmonaire chronique parait déjà mal tolérée (dyspnée accentuée et parfois cyanose), sans être cependant accompagnée d'insuffisance ventriculaire droite, la P.V.D.M. reste normale $(13$ à $18 \mathrm{~cm}$. d'eau, soit 10 à $15 \mathrm{~mm}$. de mercure). Ces résultats, un peu insolites, ne s'expliquent pas par des considératicns d'âge et de sexe, et leur mécanisme nous échappe encore. Ils sont d'ailleurs relativement rares it n'empêchent pas d'admettre que l'augmentation de la P.V.D.M. marche de pair avec la gravité de la maladie: elle représente probablement un des facteurs décisifs dans l'évolution et le pronostic d'une affection broncho-pulmonaire chronique. Nos recherches semblent donc confirmer l'opinion classique.

Nos constatations sont en harmonie avec celles de Cournand, effectuées à l'aide d'une technique plus précise (enregistrement, avec un manomètre à membrane de Hamilton, de courbes étalonnées de la pression ventriculaire droite, systolique, diastolique et différentielle). Par cette méthode, Cournand admet que chez l'homme normal la pression ventriculaire droite systolique varie entre 18 et $30 \mathrm{~mm}$. de mercure, avec une valeur moyenne de $25 \mathrm{~mm}$. de mercure. Chez 17 sujets atteints d'emphysème ou de sclérose pulmonaire sans gros coeur, la pression ventriculaire droite systolique s'est montrée 4 fois normale (autour de $24 \mathrm{~mm}$. de mercure) et 13 fois élevée ( 44 à $45 \mathrm{~mm}$. de mercure).

Dans un autre travail, Bloomfield, et al. (1946) relèvent les résultats suivants qui portent sur 20 mesures effectuées chez 19 sujets atteints d'emphysème ou de sclérose pulmonaire sans insuffisance ventriculaire droite: pression systolique, 16 à $57 \cdot 5$ $\mathrm{mm}$. de mercure; pression différentielle (pulse pressure), 16 à $54 \mathrm{~mm}$. de mercure. Chez deux autres malades où l'affection se compliquait d'insuffisance ventriculaire droite évidente, la pression systolique était de 35 et $77 \mathrm{~mm}$. de mercure et la pression différentielle de 21 et $68 \mathrm{~mm}$. de mercure. De ses recherches, Cournand conclut:

“(a) That pulmonary hypertension had not developed in cases with moderate degree of emphysema, (b) but that in the group with the most marked degree of emphysema, hypertension in the lesser circulation was present, and finally, (c) that in the group with fibrosis and moderate emphysema and apparently small heart, pulmonary hypertension was already quite marked. For a time, it was our impression that polycythemia played a decisive role in the early development of pulmonary hypertension by increasing the resistance to flow."

Nous avons aussi cherché s'il n'existerait pas des signes cliniques, radiologiques ou électriques susceptibles de faire prévoir l'hypertension dans la circulation artérielle pulmonaire. Le plus souvent, il n'est pas possible d'en inférer du syndrome clinique à la pression ventriculaire droite. Cependant, sur 7 cas où la cyanose était présente, la P.V.D.M. s'est montrée franchement augmentée 5 fois. Sur 4 cas où l'axe électrique du coeur était vertical, la P.V.D.M. 
était nettement augmentée 3 fois. Enfin, elle était franchement élevée dans les 4 cas d'axe électrique droit. Ce dernier signe, d'après notre expérience personnelle, parait donc être un indice à peu près certain de forte hypertension pulmonaire. Mais nous ne croyons pas devoir attribuer d'importance à l'amplitude augmentée des ondes auriculaires $P$ dans les deuxième et troisième dérivations, et notre élève Ferrero publiera prochainement ses constatations à ce sujet.

Comme nous l'avons déjà signalé, la présence d'une insuffisance ventriculaire droite d'origine pulmonaire est, elle aussi, un test généralement décisif d'hypertension dans, la circulation pulmonaire.

\section{SUMMARY}

La pression ventriculaire droite moyenne (P.V.D.M.) est étudiée dans 41 cas d'affections broncho-pulmonaires chroniques (asthme, emphysème, cyphoscoliose, etc. ....) avec ou sans insuffisance ventriculaire droite.

Chez 20 malades dont l'affection est bien tolérée, la P.V.D.M. est 14 fois normale, 3 fois à peine supérieure à la normale, 3 fois modérément augmentée. Le chiffre moyen, calculé sur ces 20 cas, est de $18.7 \mathrm{~cm}$. d'eau, ou $14 \mathrm{~mm}$. de mercure, c'est-àdire voisin de la normale $(15.5 \mathrm{~cm}$. d'eau ou $12 \mathrm{~mm}$. de mercure).

Chez 21 malades, qui ont permis 22 explorations et dont l'affection est mal tolérée, la P.V.D.M. s'est montrée 4 fois normale, 2 fois à peine supérieure à la normale et 16 fois franchement ou considérablement augmentée (jusqu'à 3 et même 5 fois la valeur normale). Le chiffre moyen calculé sur ces 22 mesures est de $33 \mathrm{~cm}$. d'eau ( $25 \mathrm{~mm}$. de mercure), soit plus du double du chiffre normal.

Sauf rares exceptions, plus la maladie bronchopulmonaire est sévère, et plus l'hypertension ventriculaire droite est accentuée. Le fait est particulièrement évident quand existe une insuffisance ventriculaire droite avérée, ou quand l'axe électrique du coeur est dévié à droite.

Dans ' les affections broncho-pulmonaires chroniques, l'élévation de la pression ventriculaire droite (ou artérielle pulmonaire) représente probablement un des facteurs essentiels de l'évolution vers l'insuffisance ventriculaire droite.

\section{REFERENCES}

Bing, R. J., Vandam, L. D., et Gray, F. D., Jr. (1947). Johns Hopkins Hosp. Bull., 80, 107 et 121.

Bloomfield, R. A., Lauson, H. D., Cournand, A., Breed, E. S., and Richards, D. W., Jr. (1946). J. Clin. Invest., 25, 639.

Cournand, A. (1946). Meeting of New York Academy of Medicine, 7 Mars.

Lauson, H. D., Bloomfield, R. A., Breed, E. S., Baldwin, E. F., and Cournand, A. (1943). Meeting of New York Section of Society for Experimental Biology and Medicine, 15 Dec.

Lenegre, J., et Maurice, P. (1944). Arch. mal. coeur, 37, 101, et Bull. Mém. Soc. Méd. Hôp., Paris, 60, 239.

Lenegre, J., et Maurice, P. (1947). Stanford Med. Bull., 5,61 .

(1947). Acta Cardiologica, $2,1$.

Maurice, S. (1946). La pression ventriculaire droite chez l'homme. Louis Arnette, edit., Paris.

McMichael, J., and Sharpey-Schafer, E. P. (1944). Brit. Heart J., 6, 33.

Richards, D. W., Jr., Cournand, A., Darling, R. C., and Gillespie, W. H. (1941). Tran. Ass. Amer. Phys., 56, 218.

Tybjaerg Hansen, A., et Warburg, E. (1947). Amer. Heart J., 33, 709.

\section{Pulmonary Heart Disease}

\section{BY W. D. W. BROoKs, London}

I propose in this discussion to examine some of the causes and the consequences of hypertension in the pulmonary circulation, particularly in so far as the lungs are concerned. Hypertension in the pulmonary circulation increases the work of the right ventricle and in certain circumstances may cause pulmonary heart disease. The process may be acute, or may occur gradually and be chronic.

Acute Cor Pulmonale. The most frequent cause is the sudden obstruction of a considerable proportion of the pulmonary circulation by embolism from a systemic venous thrombus usually in the pelvis, abdomen, or leg. The phenomenon not unfrequently follows an operation. Occasionally the embolus derives from the right side of the heart itself. Fat embolism too may give this result. Very rarely an aortic aneurysm ruptures into the pulmonary artery and causes acute cor pulmonale.

No primary pulmonary disorder is known that gives rise to acute cor pulmonale. It has not been reported to occur for example, as a result of blast, irradiation burns of the lungs, or of any acute infection. Spontaneous pneumothorax, even when bilateral, does not have this consequence, presumably because the blood flow into the thorax and through 
the lungs is reduced proportionately as the intrapleural pressures increase and the lungs shrink. A respiratory death is the rule.

On one occasion during the war a traumatic diaphragmatic hernia was seen to give rise to acute cor pulmonale. A sailor, aged 27, in 1942 fell down a ladder on a destroyer and was admitted to R.N.H. Chatham eight hours later. Pain in the front of the chest, dyspnœa, and shock were marked features of the case, and he had a very large (left) traumatic diaphragmatic hernia containing the stomach and some coils of intestine, and the mediastinum was grossly displaced. The size of the hernia continued rapidly to increase because the stomach was so kinked on its pyloric attachments that complete obstruction at that level resulted. Increasing systemic venous pressure, enlargement of the liver, together with clinical and radiological evidence of dilatation of the right ventricle became evident. At this time an electrocardiogram showed negative $T$ waves in leads II and III, and a prominent $Q$ in lead III. The passage of a stomach tube and other measures gave some relief, but he died on the operating table. Only one other instance of this sequence of events has been recorded (McGinn, S., and Spear, L. M.: New England J. Med. (1941), 224, 1014).

While considerable attention has been paid to the cardiovascular phenomena in acute cor pulmonale the consecutive pulmonary sequelæ have been somewhat neglected. They are not unimportant. As a direct consequence of the rapid rise in pulmonary vascular pressure the lungs become less easily altered in volume and shape. Respiration thus requires more muscular effort, the intrapleural pressure fluctuates at a more nearly atmospheric level, and may exceed atmospheric pressure during expiration. The chest can be seen to be relatively distended in expiration, so that in the more usual type of case it seems highly probable that despite extensive infarcts the residual air is relatively and perhaps absolutely increased. The vital capacity is reduced, sometimes almost to the level of the tidal air. No doubt pain too contributes to cause shallow respiration. Moreover, there may well be enough distension of the residual patent pulmonary capillaries to reduce the efficiency of gas interchange at the alveolar surface. All this occurs acutely and there is little time for adjustment and compensation to take place, in contrast to what happens when, for example, congestive heart failure supervenes on mitral stenosis. As a consequence, and apart altogether from the cardiac effects respiratory inefficiency acute and severe in degree gives rise to anoxæmia, makes the issue more hazardous, and the need for oxygen therapy more urgent. The later results of pulmonary infarction in those patients who survive are well known and need not detain us.

Chronic Cor Pulmonale. Though the pressure in the right ventricle and pulmonary artery can now be measured directly the procedure is scarcely yet one which can be called a routine clinical method. As a rule, therefore, the diagnosis of pulmonary hypertension depends upon an understanding of the disorders capable of producing it, and upon the recognition of the clinical features that they may produce.

These disorders are numerous but they fall into four groups:

(1) obstruction of the pulmonary circulation within its own limits, e.g. in emphysema, and in certain pulmonary fibroses;

(2) obstruction of the pulmonary circulation beyond its structural limits, e.g. in the left ventricular failure, and in mitral stenosis;

(3) shunting of blood from the arterial into the pulmonary circulation in, e.g. certain instances of congenital heart disease; and

(4) in severe deformity of the thoracic bony structures, e.g. severe kyphoscoliosis.

In conformity with our original limitation discussion will be restricted to the association of emphysema and pulmonary fibrosis with pulmonary hypertension and chronic cor pulmonale.

Symptoms and Signs. Dyspnœa is the outstanding symptom. It is, of course, a major clinical feature of both these disorders but with the advent of pulmonary hypertension it becomes progressively worse and ultimately incapacitates the patient. Cough is frequently but not always present, and it is productive when chronic bronchitis or passive congestion of the lungs complicate the case. When the right ventricle fails the systemic veins become more distended, the liver enlarges and often becomes tender, and odema, ascites, oliguria, and sometimes nausea and vomiting occur.

When the heart enlarges it is the conus arteriosus and right ventricle that are predominantly concerned, and the latter, occupying a greater proportion of the heart's anterior surface than is normal may give rise to visible and palpable pulsation in the third and fourth left intercostal spaces. The pulmonary second sound is accentuated, and later gallop rhythm may be heard. Less constant and very variable features are cyanosis, clubbing of the fingers and toes, and polycythæmia. To these will be added the well-known symptoms and physical signs of the underlying pulmonary abnormality. It will be observed that a majority of the clinical features of pulmonary hypertension are also features of emphysema and of certain pulmonary fibroses such as the pneumokonioses. Only when failure 
of the right heart develops, do distinctive symptoms and signs arise. For this reason, the early recognition of pulmonary hypertension is greatly helped by radiological examination. The distended pulmonary vessels can as a rule be seen spreading far out into the lungs, and the aggregate of major pulmonary vascular trunks at the hila are much more dominant a feature than is usual. I am indebted to my colleague, Dr. E. Rohan Williams, for his demonstration that enlargement of the pulmonary artery near the hilum can often especially well be shown by radiography in the lordotic position. Tomography also can demonstrate these dilated vessels beautifully.

It hās long been assumed that emphysema causes pulmonary hypertension and ultimately cor pulmonale by progressive obliteration of the capillaries within the lungs. The major weakness in this hypothesis is the lack of correlation between the degree of emphysema and the accompanying cardiovascular change. Parkinson and Hoyle (1937) (Quart. J. Med., 6, 59) summarize the historical background and set forth this difficulty so well that I need only cite this one report. In the last ten years the part played by consecutive arteriosclerotic changes particularly in the pulmonary arterioles has been emphasized in several reports of which (Parker, R. L. (1940), Ann. intern. Med., 14, 795; and Gilmour, J. R., and Evans, H. (1946) J. Path. Bact., 56, 587) are noteworthy. The last authors in a case of primary pulmonary hypertension reported aplasia or hypoplasia in innumerable small pulmonary arteries, and concluded that this deficiency was a factor leading to the later genesis of endarteritis and pulmonary hypertension. From these reports it would seem likely that in emphysema associated arteriosclerosis in the pulmonary arterioles is a requisite for the development of cor pulmonale.
It is not yet clear to what extent in emphysema the obliteration of capillaries and hypertension from this source causes arteriolar sclerosis. Cases occur in which pulmonary arteriosclerosis arises independently of any pulmonary disease or indeed of any known cause so that other factors may be concerned. There are few if any comparable investigations in patients with pneumonokoniosis.

It was thought worth while to investigate series of normals, of emphysema, and of pneumonokoniosis with and without pulmonary hypertension, and to compare the cardiac output, cardiac area, and lung volumes in these series in the hope that some correlation between the pulmonary pathology and the extent of the pulmonary hypertension might be found.

\section{Results}

The results of the estimation of the cardiac output and lung volumes in 12 normal controls of similar ages to those of the cases of emphysema and fibrosis are set forth in Table I. Basal conditions obtained throughout.

Cardiac output showed a variation dependent on difference in size of the individuals, the cardiac index being nearly constant. Mean C.I. $=2 \cdot 2$ lit. per sq. metre: probable error \pm 0.083 . The cardiac area as determined by a planimeter from standard posteroanterior radiograms was $173 \cdot 3 \pm 5 \cdot 11$ sq. $\mathrm{cm}$. The value of the total pulmonary capacity and its subdivisions, the vital capacity and residual air, fell within the limits of normality in regard to both relative and absolute values of these quantities.

Emphysema. Fifteen male patients were investigated. Their physical and clinical characteristics, the duration of symptoms, the signs, and the X-ray and cardiographic findings were recorded. Their disability ranged from dyspnœa on moderate exertion to dyspnœa at rest. Cyanosis, while the

TABLE I

NORMALS

\begin{tabular}{|c|c|c|c|c|c|c|c|}
\hline Case & $\begin{array}{l}\text { Cardiac } \\
\text { output }\end{array}$ & $\begin{array}{c}\text { Cardiac } \\
\text { index }\end{array}$ & $\begin{array}{c}\text { Cardiac } \\
\text { area }\end{array}$ & T.P.C. * & V.C. * & R.A. * & $\frac{\mathrm{RA}}{\mathrm{TPC}} \times 100$ \\
\hline $\begin{array}{r}1 \\
2 \\
3 \\
4 \\
5 \\
6 \\
7 \\
8 \\
9 \\
10 \\
11 \\
12\end{array}$ & $\begin{array}{l}3 \cdot 70 \\
4 \cdot 26 \\
4 \cdot 38 \\
2 \cdot 47 \\
3 \cdot 56 \\
5 \cdot 04 \\
4 \cdot 46 \\
4 \cdot 06 \\
3 \cdot 92 \\
3 \cdot 14 \\
5 \cdot 38 \\
4 \cdot 71\end{array}$ & $\begin{array}{l}1 \cdot 74 \\
2 \cdot 23 \\
2 \cdot 11 \\
1.44 \\
1.99 \\
2.93 \\
2 \cdot 13 \\
2.06 \\
2 \cdot 20 \\
2 \cdot 11 \\
3 \cdot 18 \\
2.35\end{array}$ & $\begin{array}{l}204 \\
168 \\
202 \\
191 \\
189 \\
128 \\
152 \\
181 \\
133 \\
145 \\
193 \\
187\end{array}$ & $\begin{array}{l}7 \cdot 08 \\
6 \cdot 57 \\
5 \cdot 27 \\
6 \cdot 56 \\
5 \cdot 46 \\
4 \cdot 66 \\
7 \cdot 80 \\
7 \cdot 10 \\
4 \cdot 47 \\
3 \cdot 76 \\
4 \cdot 31 \\
8 \cdot 56\end{array}$ & $\begin{array}{l}5 \cdot 80 \\
5 \cdot 30 \\
4 \cdot 19 \\
4.90 \\
3.95 \\
3 \cdot 48 \\
5 \cdot 70 \\
5 \cdot 10 \\
3 \cdot 20 \\
2.64 \\
2.95 \\
5.73\end{array}$ & $\begin{array}{l}1.28 \\
1.27 \\
1.08 \\
1.66 \\
1.51 \\
1.18 \\
2.10 \\
2.00 \\
1.27 \\
1.12 \\
1.36 \\
2.83\end{array}$ & $\begin{array}{l}18 \cdot 1 \\
19 \cdot 3 \\
20 \cdot 5 \\
25 \cdot 3 \\
27 \cdot 7 \\
25 \cdot 3 \\
26 \cdot 9 \\
28 \cdot 2 \\
28 \cdot 4 \\
29 \cdot 8 \\
31 \cdot 5 \\
33 \cdot 1\end{array}$ \\
\hline
\end{tabular}

* T.P.C., total pulmonary capacity; V.C., vital capacity; and R.A., residual air. 
TABLE II

EMPHYSEMA

\begin{tabular}{|c|c|c|c|c|c|c|c|}
\hline Case & $\begin{array}{l}\text { Cardiac } \\
\text { output }\end{array}$ & $\begin{array}{c}\text { Cardiac } \\
\text { index }\end{array}$ & $\begin{array}{c}\text { Cardiac } \\
\text { area }\end{array}$ & T.P.C. & V.C. & R.A. & $\frac{\mathrm{RA}}{\mathrm{TPC}} \times 100$ \\
\hline $\begin{array}{l}13 \\
14 \\
15 \\
16 \\
17 \\
18 \\
19 \\
20 \\
21 \\
22 \\
23 \\
24 \\
25 \\
26 \\
27\end{array}$ & $\begin{array}{l}6 \cdot 96 \\
7 \cdot 60 \\
4 \cdot 51 \\
8 \cdot 30 \\
3 \cdot 59 \\
6 \cdot 36 \\
7 \cdot 39 \\
4 \cdot 34 \\
6 \cdot 13 \\
4 \cdot 72 \\
3 \cdot 26 \\
5 \cdot 84 \\
4 \cdot 94 \\
3 \cdot 74 \\
5 \cdot 30\end{array}$ & $\begin{array}{l}3 \cdot 36 \\
4 \cdot 04 \\
3 \cdot 30 \\
4 \cdot 19 \\
2.05 \\
3 \cdot 60 \\
3 \cdot 47 \\
2 \cdot 89 \\
4 \cdot 41 \\
2 \cdot 36 \\
1 \cdot 71 \\
3.06 \\
3 \cdot 38 \\
2.63 \\
2.76\end{array}$ & $\begin{array}{l}213 \\
184 \\
194 \\
268 \\
192 \\
174 \\
206 \\
169 \\
129 \\
210 \\
165 \\
181 \\
114 \\
109 \\
299\end{array}$ & $\begin{array}{l}5 \cdot 73 \\
6 \cdot 45 \\
4 \cdot 11 \\
7 \cdot 71 \\
5 \cdot 55 \\
4 \cdot 54 \\
4 \cdot 29 \\
6 \cdot 58 \\
4 \cdot 20 \\
6 \cdot 47 \\
5 \cdot 46 \\
6 \cdot 90 \\
4 \cdot 66 \\
4 \cdot 77 \\
5 \cdot 84\end{array}$ & $\begin{array}{l}4.04 \\
4.54 \\
2.72 \\
4.95 \\
3.50 \\
2.74 \\
2.56 \\
3.92 \\
2.48 \\
3.80 \\
3 \cdot 18 \\
3.80 \\
2.46 \\
2.04 \\
1.77\end{array}$ & $\begin{array}{l}1.69 \\
1.91 \\
1.39 \\
2.76 \\
2.05 \\
1.80 \\
1.73 \\
2.66 \\
1.72 \\
2.67 \\
2.28 \\
3.10 \\
2.20 \\
2.73 \\
4.07\end{array}$ & $\begin{array}{l}29 \cdot 5 \\
29 \cdot 6 \\
33 \cdot 8 \\
35 \cdot 8 \\
36 \cdot 9 \\
39 \cdot 7 \\
40 \cdot 3 \\
40 \cdot 4 \\
41 \cdot 0 \\
41 \cdot 3 \\
42 \cdot 2 \\
44 \cdot 9 \\
47 \cdot 2 \\
57 \cdot 2 \\
69 \cdot 6\end{array}$ \\
\hline
\end{tabular}

patient was resting, was present in eight, but clubbing of the fingers was noticeable in one patient only. In two cases $(16,27)$ the chronic pulmonary disorder was complicated by hyperpiesis. Pulmonary hypertension could be diagnosed in eleven cases, and cor pulmonale in five - as a result of an aggregate of the above and subsequent findings. (Cases 13, 16, 17, $18,19,20,22,23,24,26,27$ : and $13,16,19,22$, and 27 respectively).

In Table II the cases (as in Table I) are set forth in order of the severity of the emphysema as measured by the relative size of the residual air $\frac{\mathrm{RA}}{\mathrm{TPC}} \times 100$. No correlation could be found between this ratio and the estimated degree of pulmonary hypertension, nor with the incidence or severity of cor pulmonale when that was present.

The cardiac output and index were as a rule higher than had been found in normal controls, and this was also true in cases with cor pulmonale.

The cardiac area, apart from Cases 16 and 27, both of which had systemic hypertension, was essentially the same as that found in the normal controls; the mean cardiac area being $172 \cdot 7 \pm 6 \cdot 6$ sq. $\mathrm{cm}$. Vital capacity was reduced, residual air increased so that $\frac{\mathrm{RA}}{\mathrm{TPC}} \times 100$ was increased. The total pulmonary capacity was not greatly abnormal.

Fibrosis. A similar investigation of 14 cases of pneumonokoniosis was undertaken. Dyspnœa was an even more noticeable feature and cyanosis at rest was apparent in 9 cases.

Six patients had been sand blasters, five coal miners, and one an iron moulder, while in two no recognized industrial hazard productive of pneumonokoniosis had occurred in their history. The duration of exposure was noticeably short in those whose occupation had been sand blasting. In four cases electrocardiography showed left ventricular preponderance and two of these presented evidence of systemic arteriosclerosis and a high blood pressure.

In Table III the degree of pulmonary fibrosis varied from slight to very severe as judged radiologically, but the X-ray findings bore little or no relation to the patient's disability as measured by dyspnœa or to the ratio $\frac{\mathrm{RA}}{\mathrm{T}} \overline{\mathrm{PC}} \times 100$. In five (Cases $30,37,39,41)$ pulmonary hypertension could be diagnosed and in two (Cases 30 and 37) cor pulmonale was present. Again there was no correlation to be found between the severity of the respiratory disorder as measured by $\frac{\mathrm{RA}}{\mathrm{TPC}} \times 100$ and the observed consecutive cardiovascular abnormality or between the latter and the radiological extent of the disease. Cardiac output was often raised and this was true also in those with cor pulmonale. The mean cardiac area (excluding the two cases with systemic hypertension) was $185.8 \pm 4.9$ sq. $\mathrm{cm}$. which showed a slight statistically significant increase as compared with the normals.

The total pulmonary capacity was decreased as a result of a marked decrease in the vital capacity, the residual air being absolutely and relatively increased.

These results confirm previous findings that correlation is lacking between the severity of emphysema and the associated degree of pulmonary hypertension and cor pulmonale. They also show a similar lack of relationship to obtain in cases of pneumonokoniosis-which has not previously been reported. 
TABLE III

FibRosis

\begin{tabular}{|c|c|c|c|c|c|c|c|}
\hline Case & $\begin{array}{l}\text { Cardiac } \\
\text { output }\end{array}$ & $\underset{\text { index }}{\text { Cardiac }}$ & $\begin{array}{c}\text { Cardiac } \\
\text { area }\end{array}$ & T.P.C. & V.C. & R.A. & $\frac{\mathrm{RA}}{\mathrm{TPC}} \times 100$ \\
\hline $\begin{array}{l}28 \\
29 \\
30 \\
31 \\
32 \\
33 \\
34 \\
35 \\
36 \\
37 \\
38 \\
39 \\
40 \\
41\end{array}$ & $\begin{array}{l}4 \cdot 54 \\
3.81 \\
5 \cdot 28 \\
7 \cdot 48 \\
2.92 \\
4 \cdot 77 \\
2 \cdot 87 \\
4 \cdot 89 \\
4 \cdot 68 \\
4 \cdot 77 \\
2.98 \\
6 \cdot 13 \\
8.98 \\
6 \cdot 25\end{array}$ & $\begin{array}{l}2.40 \\
2.25 \\
3.03 \\
3.84 \\
1.90 \\
3.11 \\
1.95 \\
3.09 \\
2.56 \\
2.69 \\
2.07 \\
3.29 \\
6.36 \\
3.80\end{array}$ & $\begin{array}{l}161 \\
237 \\
203 \\
168 \\
155 \\
183 \\
180 \\
168 \\
157 \\
222 \\
176 \\
306 \\
170 \\
282\end{array}$ & $\begin{array}{l}2 \cdot 88 \\
5 \cdot 32 \\
4 \cdot 58 \\
4 \cdot 36 \\
4 \cdot 01 \\
3.99 \\
2.75 \\
4 \cdot 12 \\
4 \cdot 33 \\
4 \cdot 35 \\
7 \cdot 20 \\
3 \cdot 55 \\
4 \cdot 48 \\
3.89\end{array}$ & $\begin{array}{l}2.20 \\
3.87 \\
3.16 \\
2.68 \\
2.30 \\
2.24 \\
1.54 \\
2.18 \\
2.22 \\
2.18 \\
3.24 \\
1.50 \\
1.68 \\
1.06\end{array}$ & $\begin{array}{l}0.68 \\
1.45 \\
1.42 \\
1.68 \\
1.71 \\
1.75 \\
1.21 \\
1.94 \\
2.11 \\
2.17 \\
3.96 \\
2.05 \\
2.80 \\
2.83\end{array}$ & $\begin{array}{l}23 \cdot 6 \\
27.2 \\
31.0 \\
38.5 \\
42 \cdot 6 \\
43.8 \\
44.0 \\
47.0 \\
48 \cdot 7 \\
49.9 \\
55 \cdot 0 \\
57 \cdot 7 \\
62.5 \\
72.7\end{array}$ \\
\hline
\end{tabular}

In both emphysema and pneumonokoniosis progressive obliteration of small pulmonary vessels occurs which could theoretically ultimately cause pulmonary hypertension. In both disorders the distruction of available effective alveolar surface for oxygenation could give rise to decreased arterial oxygen saturation of the blood and so in turn theoretically cause a "work hypertrophy" and ultimately failure of the heart. In neither disease, however, can the severity of the pathological process be directly related to the observed associated cardiovascular change; and therefore it seems probable that when pulmonary hypertension or cor pulmonale develops some other causal factor, unrelated to the primary pulmonary disease, must be present.

\section{Electrocardiographic Appearances in Acute and Chronig Pulmonary Heart Disease}

\section{By Paul Wood, London}

An analysis of the electrocardiographic appearances in 20 cases of massive pulmonary embolism with raised jugular venous pressure was presented. Limb leads showed an almost constant $\mathbf{S}$ wave in lead I, frequent $Q$ wave in lead III, inversion of $\mathrm{T}$ III, flattening or slight inversion of T II, and rather low voltage. Occasionally P II was tall and sharp. Multiple chest leads revealed inversion of $\mathrm{T}$ from V I to V 3 or 4 in all, reversion to normal taking three to six weeks. Transient right bundlebranch block occurred in three. The changes were attributed to acute right ventricular stress.

In 100 cases of chronic pulmonary heart disease, limb leads showed a tall sharp $P$ wave in 85 , right axis deviation in 46 , a tendency to right axis deviation in 11, a prominent $S$ wave in all leads in 9, right bundle-branch block in 4 , and low voltage in 40. Multiple chest leads showed normal ventricular deflections in the majority; inversion of $T$ from V 1 to V 3 occurred in only 13 per cent and a chiefly upright QRS complex in V 1 with a conspicuous $S$ wave in V 5 was seen in only 16 per cent. In another 16 per cent of cases anterior chest leads from V 1 to V 5 revealed a fixed RS pattern with $S$ dominant. It was concluded that the tall spiked
P wave was by far the most significant change. The rest of the communication summarized the author's investigations into this $P$ wave. In normal controls the maximum auricular deffection very rarely measured more than $1.5 \mathrm{~mm}$. in amplitude and averaged $1 \mathrm{~mm}$. The pulmonary $P$ wave commonly ranged between $2-3 \mathrm{~mm}$. in height, but was never widened. It was never seen in normal vertical hearts which refuted the suggestion that it depended on cardiac rotation due to emphysema. It could not be attributed to anoxia for it was an early finding and tended to diminish in voltage when anoxia became severe, nor was it present in cases of severe anæmia. It could not be ascribed to an elevated cardiac output; for it was seen in a much less conspicuous form in cases of thyrotoxicosis in which the cardiac output was considerably higher; moreover, as already mentioned, $\mathbf{P}$ was of low voltage in severe chronic anæmia with outputs up to 14 litres a minute. Intracardiac pressure studies failed to reveal any correlation between this $P$ wave and the right auricular pressure, but there appeared to be some association between it and the right ventricular pressure. Just on what such a relationship might depend was unknown. 